\title{
Metode Line Profile untuk Menganalisis Citra Ultrasonografi pada Pemeriksaan Peripheral Arterial Disease (PAD)
}

\author{
Ni Larasati Kartika Sari ${ }^{*}$, Rizky Hidayatulloh ${ }^{1}$, Samsun $^{2}$ \\ ${ }^{1}$ Program Studi Fisika, Universitas Nasional (Pasar Minggu, Jakarta Selatan 12520) \\ ${ }^{2}$ Politeknik Kesehatan Jakarta II (Kebayoran Baru, Jakarta Selatan 12120) \\ *Korespondensi penulisa: tikpo09@gmail.com
}

\begin{abstract}
Abstrak. Penelitian ini bertujuan menganalisis profil nilai piksel pada citra USG Peripheral Alrterial Disease (PAD) dengan metode line profile, menghitung nilai SNR dan mengembangkan program peningkatan kualitas citra menggunakan berbagai algoritma filtering dan contrast enhancement. Metode penelitian yang digunakan bersifat eksperimental melalui pengumpulan data citra normal dan abnormal lalu peningkatan kualitas citra menggunakan 3 filtering yaitu median filter, gaussian filter, wiener filter dikombinasi dengan 3 contrast enhancement yaitu global histogram equalization, CLAHE (Contrast Limited Adaptif Histogram Equalitation) dan Intensity Adjustment. Kemudian hasil kombinasi tersebut dihitung nilai SNR. Pengolahan citra dilanjutkan dengan line profile yaitu membuat 5 garis disetiap anatomi aliran darah PAD menggunakan ImageJ. Hasil penelitian menunjukan, secara umum, nilai SNR terbesar yaitu kombinasi antara algoritma filtering gaussian dengan global histogram equalization baik pada citra normal dan abnormal. Sementara itu, profil garis (line profile) pada citra normal menghasilkan grafik berbentuk parabola dan profil garis citra abnormal membentuk distribusi gaussian. Profile berbentuk parabola memperlihatkan bahwa nilai piksel bagian tengah citra yang menunjukkan aliran darah lebih kecil dibanding sekitarnya, yang berarti tidak terdapat penyumbatan. Sementara itu, puncak di bagian tengah profil citra abnormal menandakan citra terdapat nilai piksel tinggi. Maka daerah piksel tinggi menunjukan sumbatan pada pembuluh darah.
\end{abstract}

Kata Kunci: peripheral arterial disease, median filter, gaussian filter, wiener filter, histogram equalization, CLAHE, intensity adjustment, line profile.

\begin{abstract}
This study aims to analyzes profiles on PAD ultrasound images, calculates SNR value and develops program to improve image quality using filtering program and contrast enhancements in MATLAB. This research used experimental method through collecting normal and abnormal images and then enhanced the image quality using 3 filters, median filter, gaussian filter, and wiener filter combined with 3 contrast enhancements, histogram equalization, CLAHE (Contrast Limited Adaptive Histogram Equalitation) and Intensity Adjustment. Then the SNR value was calculate at enhanced images. The result of the image processing then analyzed with line profile method by making 5 lines in each anatomy of PAD blood flow using ImageJ. The results showed that the largest SNR value was a combination of gaussian filtering and global histogram equalization. The normal image profile line produces a parabola shape (letter $U$ ). The profile shows differences that produce a peak in the middle of the bloodstream. The peak indicates an image that has high pixels. Then the high pixel area shows blockages in the blood vessels.
\end{abstract}

Keywords: peripheral arterial disease, median filter, gaussian filter, wiener filter, histogram equalization, CLAHE, intensity adjustment, line profile.

\section{PENDAHULUAN}

Ultrasonografi (USG) salah satu pencitraan diagnostik untuk memeriksa jaringan dalam tubuh, mempelajari bentuk ukuran anatomi dan gerakan serta hubungan dengan jaringan disekitarnya. Dengan kemajuan ilmu kedokteran, para ahli terus berinovasi 
mengembangkan USG konvensional menjadi USG Doppler. USG Doppler sangat bermanfaat untuk pencitraan bagian bergerak dari tubuh, seperti sistem peredaran darah, salah satunya untuk mendiagnosis penyempitan pembuluh darah PAD (Peripheral Aterial Disease). PAD merupakan istilah yang digunakan untuk menjelaskan suatu penyakit yang menyebabkan gangguan aliran darah pada ekstremitas yang biasanya disebabkan oleh penumpukan plak (aterosklerosis) [1]. Pada tahun 2016 diperkirakan lebih dari 200 juta penduduk dunia menderita PAD [2]. Aterosklerosis menjadi penyebab paling banyak dengan kejadiannya mencapai $4 \%$ populasi usia diatas 40 tahun, bahkan $15-20 \%$ pada usia lebih dari 70. Pemprosesan citra USG dengan komputer telah terbukti dapat meningkatkan kualitas citra USG. Citra USG tersusun atas speckle noise [3]. Linear dan median filter dapat mengurangi speckle noise, namun juga menurunkan kualitas citra. Pengunaan median filter dan linear filter jenis gaussian secara bertahap terbukti mampu mengurangi noise speckle, selakigus memperjelas tepi objek dalam citra [4]. Penggunaan berbagai jenis filter dan contrast enhancement dapat meningkatkan kualitas citra USG Pankreas, dengan metode median filter member nilai MSE terendah dan PSNR tertinggi dibanding dengan domain frekuensi gaussian low-pass filter, histogram equalization dan wavelet filter [5].

Pemprosesan komputer pada citra USG tepi ginjal dengan menggunakan median filter, gaussian filter, proses histogram, filtering morfologi dan wavelet dapat meningkatkan visualisasi citra [6]. Pengolahan citra USG ginjal dengan gaussian filter dan texture features analysis juga mampu mendeskripsikan karakteristik ginjal sehat dengan baik tanpa dipengaruhi kualitas citra dari pesawat USG [7]. Selain itu pengolahan citra menggunakan berbagai jenis filter pada citra USG jaringan lunak juga dapat menghilangkan speckle noise dengan low pass gaussian filter dan shock filter menghasilkan performa penghilangan noise yang paling baik [8]. Penggunaan algoritma filtering, operasi morfologi dan segmentasi juga dapat meningkatkan visualisasi citra USG [9]. Median filter yang telah dimodifikasi telah terbukti dengan sukses dapat menghilangkan noise speckle dari citra ultrasonografi [10].

\section{METODE PENELITIAN}

Penelitian ini menggunakan alat dan bahan seperti CD-RW sebanyak 10 buah untuk mengambil citra USG doppler PAD dari pesawat, citra USG PAD sebanyak 50 buah, komputer/Laptop untuk mengolah citra, dan software Matlab 2017a. Pesawat Ultrasonografi Doppler tipe GE Logic F6 dimensi 2D dengandaya input 100-240V, 50/60 $\mathrm{Hz}, 400 \mathrm{VA}$. Pengambilan data citra menggunakan probe linear 6-12 dengan metode Doppler mode dibantu dengan gel aquasonic. Sampel yang digunakanhanya pada anatomi CFA (Common Femoral Artery), SFA (Superficial Femoral Artery), POP (Popliteal Artery) dan ATA (Anterior Tibial Artery). Masing masing anatomi diambil 5 sampel citra yang berbeda lalu dikelompokan normal dan abnormal

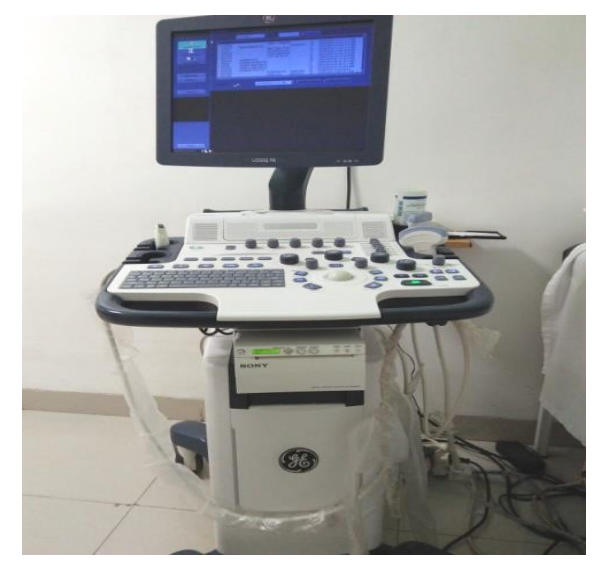

GAMBAR 1. Alat USG doppler 
Peningkatan kualitas citra dilakukan dengan menggunakan median filter, gaussian filter, wiener filter, global histogram equalization, CLAHE (contrast limited adaptive histogram equalitation) dan penajaman tepi. Masing-masing citra di kombinasikan sehingga menghasilkan 9 citra yang berbeda beda. Kesembilan kombinasi dapat dilihat pada tabel 1 . Hasil dari masing-masing kombinasi akan diukur nilai SNR nya pada software Matlab. Alur kerja program pengolahan citra dapat dilihat pada gambar 2.

TABEL 1. Kombinasi Filtering dan Contrast Enhancement

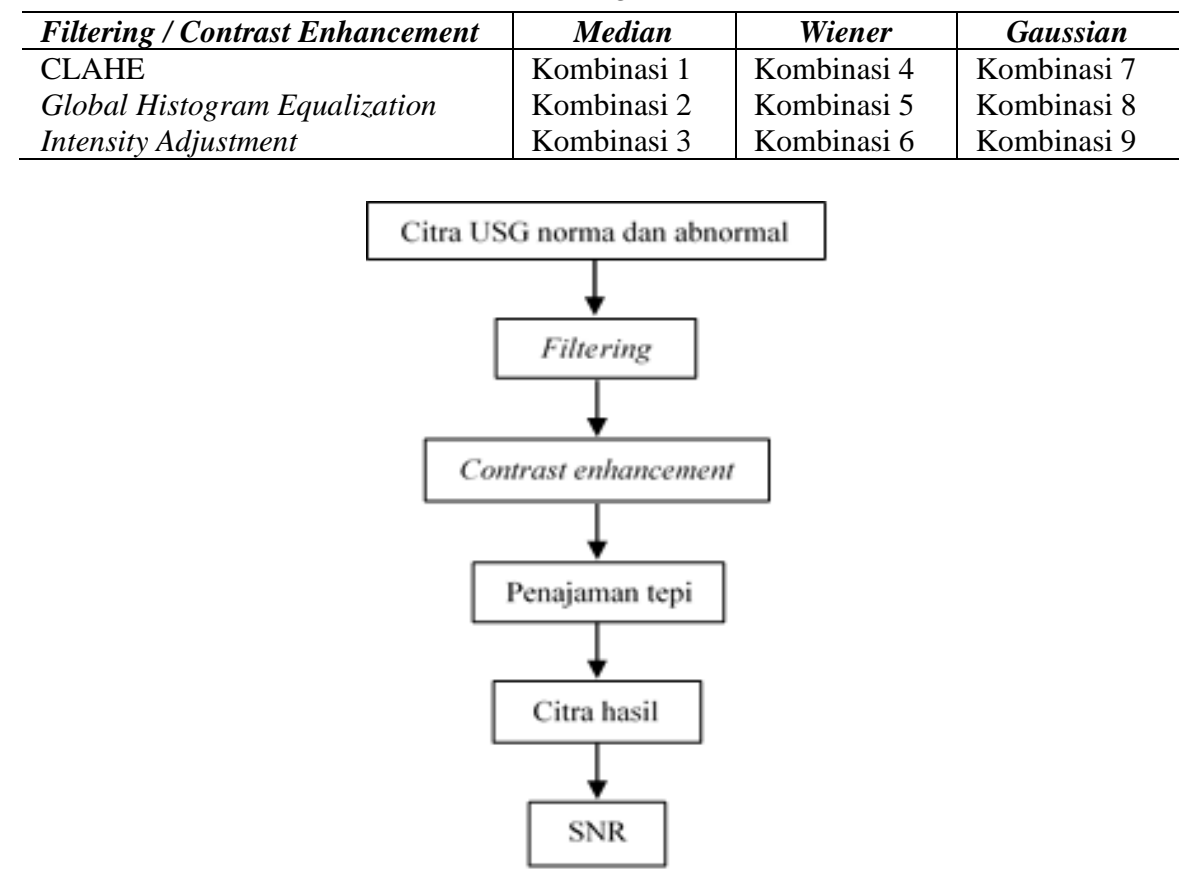

GAMBAR 2. Alur kerja program

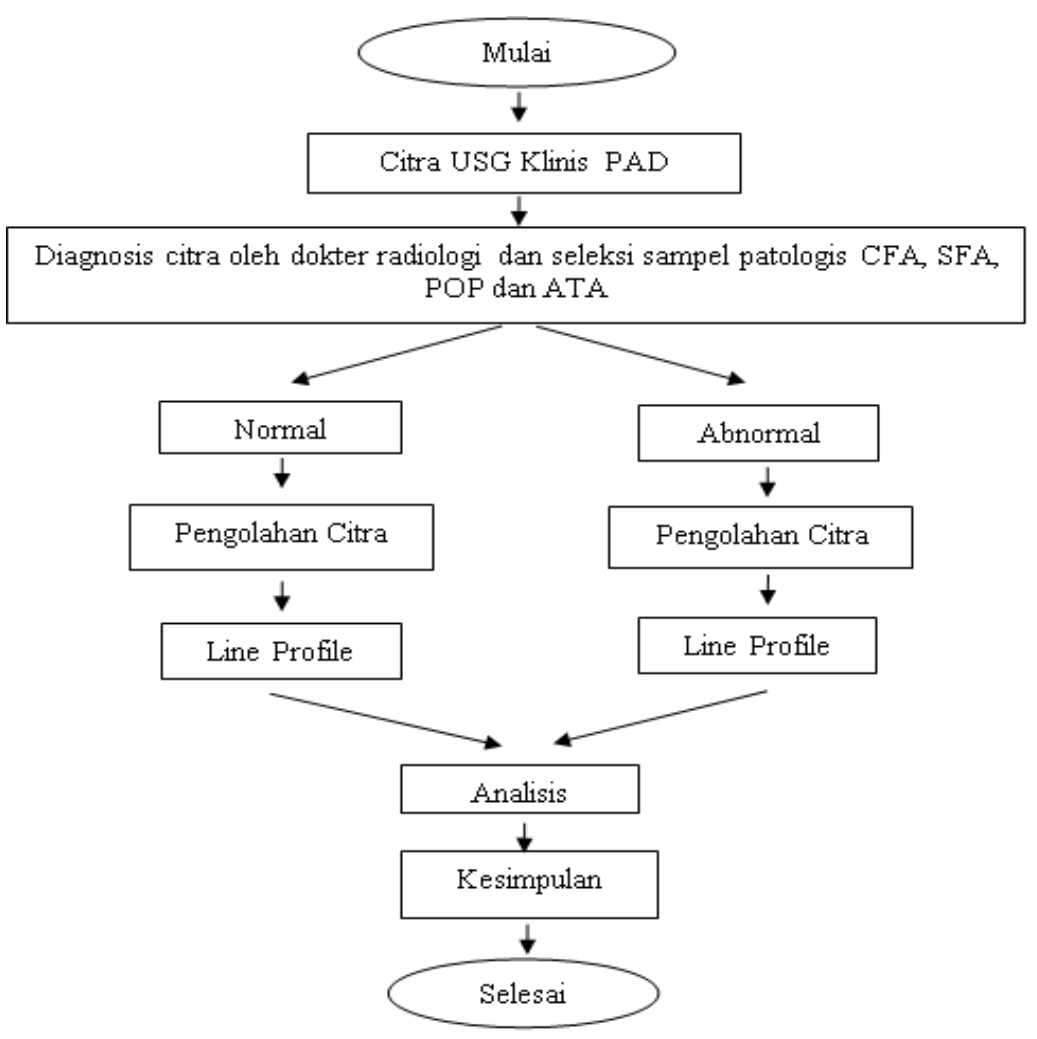

GAMBAR 3. Langkah kerja 
Setelah melalui tahapan filtering dan contrast enhancement, perbedaan karakter citra normal dan citra PAD dapat dianalisis dengan memanfaatkan metode line profile. Garis uji pada setiap citra yang dibuat untuk setiap citra terdiri dari 5 garis. Seluruh garis ditempatkan pada anatomi pembuluh darah arteri. Pembuatan garis uji dimulai dari garis antar dinding arteri. Dengan cara membuka citra yang akan dikuantisasi menggunakan software ImageJ. Lalu membuat garis uji dengan menggunakan straight line tool. Menggunakan tools ROI manager untuk membuat garis uji lebih dari satu pada tiap citra serta mengatur garis uji secara bersamaan. Kemudian pilih plot profile pada menu analyze tool untuk menghasilkan line profile dari tiap garis uji.

Analisis data pencitraan dilakukan dengan mengevaluasi nilai SNR dari tiap kombinasi metode algoritma. Kombinasi algoritma dengan Nilai SNR tertinggi merupakan kombinasi dengan performa yang paling baik dalam meningkatkan citra USG PAD. Semakin besar nilai SNR berarti pengurangan noise dapat meningkatkan kualitas citra, sebaliknya jika nilai SNR semakin kecil maka pada citra hasil hanya sedikit juga peningkatan kualitasnya. Kemudian hasil profile nilai piksel dengan metode line profile dievaluasi dengan mengamati karakteristik bentuk segmen profile pada citra normal dan abnormal. Urutan langkah kerja penelitian dapat dilihat pada gambar 3.

\section{HASIL DAN PEMBAHASAN}

\section{Hasil dan Pembahasan Pengolahan Citra}

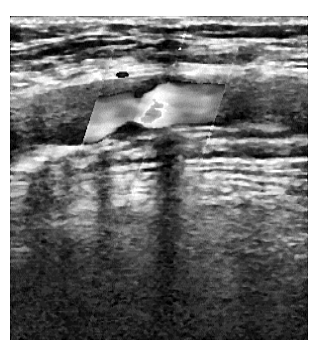

(a)

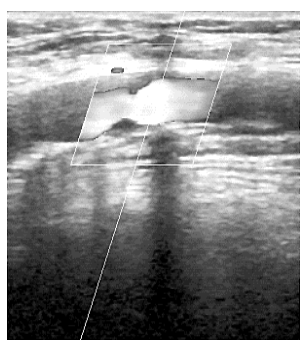

(d)

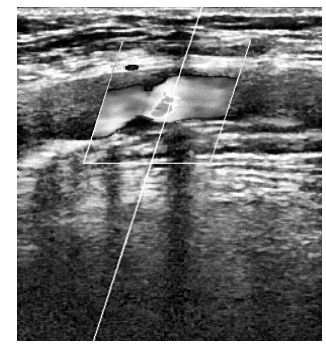

(g)

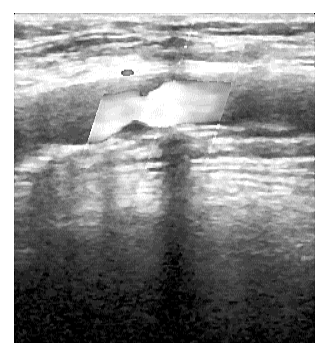

(b)

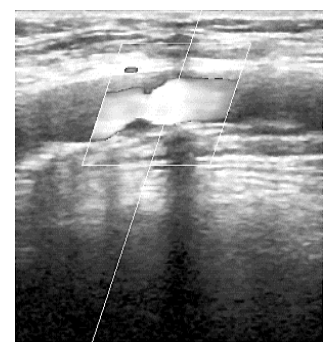

(e)

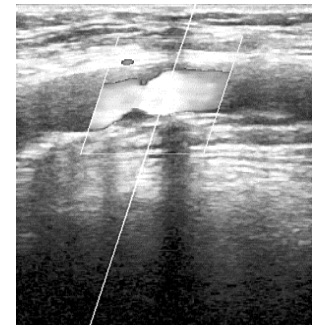

(h)

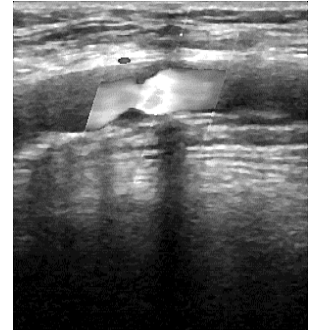

(c)

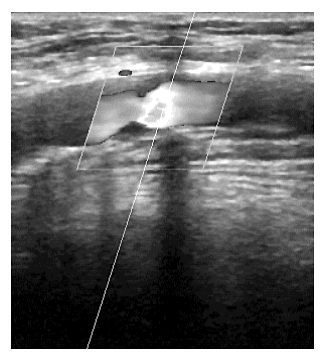

(f)

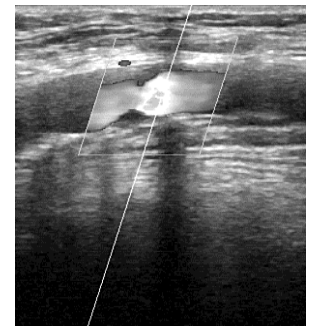

(i)

GAMBAR 4. Hasil Citra 9 kombinasi dengan anatomi CFA normal (a) kombinasi median filter dengan CLAHE (b) kombinasi median filter dengan histogram equalization (c) kombinasi median filter dengan Intensity Adjustment (d) kombinasi wiener filter dengan CLAHE (e) kombinasi wiener filter dengan histogram equalization (f) kombinasi wiener filter dengan Intensity Adjustment (g) kombinasi filtering gaussian dengan CLAHE (h) kombinasi gaussian dengan histogram equalization (i) kombinasi gaussian dengan Intensity Adjustment. 
Preprocessing citra dilakukan dengan mengkombinasi 3 filtering dan 3 contrast enhancement. Sehingga tiap citra diproses dengan metode algoritma. Dapat terlihat kombinasi median pada gambar 1, 2, 3 citra terlihat detail, namun terlihat gelap dan kasar. Kombinasi wiener pada gambar 4, 5, 6 citra lebih halus dan noise nya sedikit. Kombinasi gaussian pada gambar 7, 8, 9 lebih halus namun lebih terlihat terang. Hasil preprocessing ke 9 kombinasi tersebut dapat dilihat pada gambar 4 dan 5.

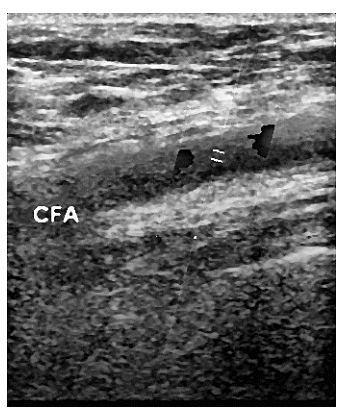

(a)

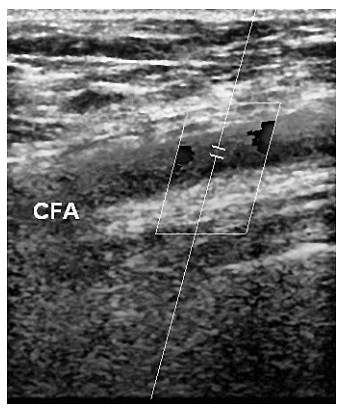

(d)

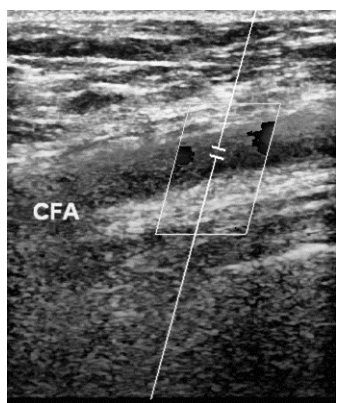

(g)

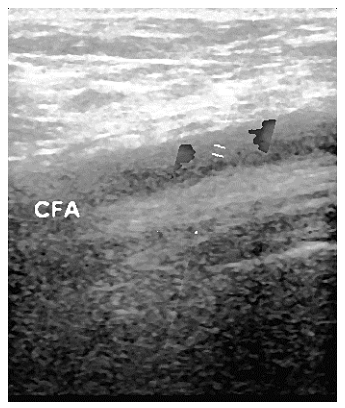

(b)

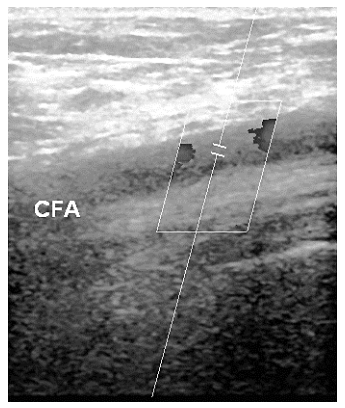

(e)

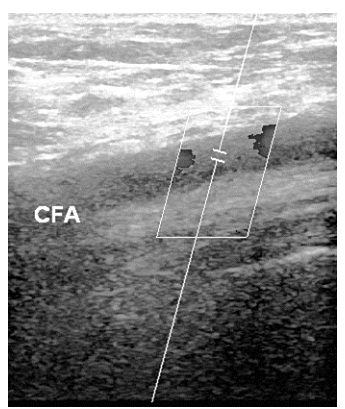

(h)

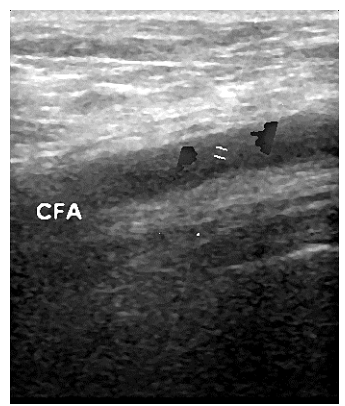

(c)

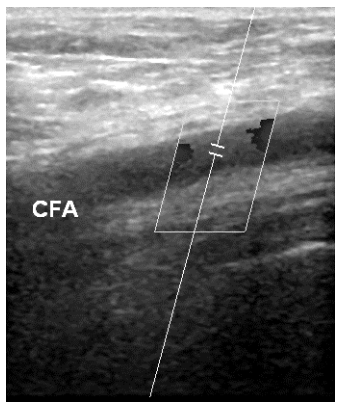

(f)

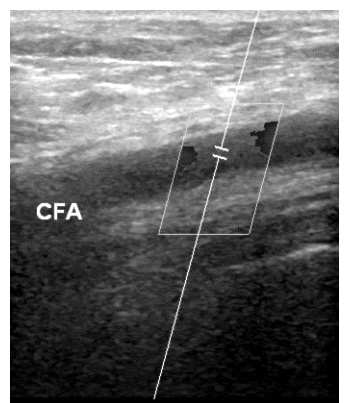

(i)

GAMBAR 5. Hasil citra 9 kombinasi dengan anatomi CFA abnormal (a) kombinasi median filter dengan CLAHE (b) kombinasi median filter dengan histogram equalization (c) kombinasi median filter dengan Intensity Adjustment (d) kombinasi wiener filter dengan CLAHE (e) Kombinasi wiener filter dengan histogram equalization (f) kombinasi wiener filter dengan Intensity Adjustment (g) kombinasi filtering gaussian dengan CLAHE (h) kombinasi gaussian dengan histogram equalization (i) kombinasi gaussian dengan Intensity Adjustment.

TABEL 2. Nilai SNR citra normal

\begin{tabular}{cccccccccc}
\hline \multirow{2}{*}{ Anatomi } & \multicolumn{10}{c}{ Kombinasi } \\
\cline { 2 - 10 } & 1 & 2 & 3 & 4 & 5 & 6 & 7 & 8 & 9 \\
\hline CFA & 19 & 75.2 & 64.1 & 19.3 & 92.9 & 54.3 & 21 & 93.8 & 48.4 \\
SFA & 17.8 & 28.5 & 21.4 & 19.8 & 27.4 & 22.2 & 17.9 & 40.5 & 23.2 \\
POP & 27 & 53.8 & 63 & 30.2 & 63.5 & 72.8 & 27.3 & 69 & 73.1 \\
ATA & 20.2 & 30.4 & 38.8 & 21.3 & 31.6 & 39.5 & 19.8 & 48.4 & 43.7 \\
\hline Rata-rata & 20.99 & 46.98 & 46.8 & 22.62 & 53.87 & 47.2 & 21.49 & 62.94 & 47.09 \\
\hline
\end{tabular}

Untuk mengevaluasi secara kuantitif, dilakukan pula pengukuran SNR. Hasil pengukuran SNR dapat dilihat pada tabel 2. Berdasarkan nilai SNR pada tabel 2 dan gambar 6 serta 7 , 
grafik citra normal tiap kombinasi memiliki keunggulan dalam menghilangkan noise pada citra dengan anatomi tertentu. Kombinasi 8 menghasilkan SNR rata-rata tertinggi pada citra normal. Kombinasi 8 merupakan gabungan dari filtering gaussian dengan histogram equalization dengan nilai rata-ratanya yaitu 62.94 .

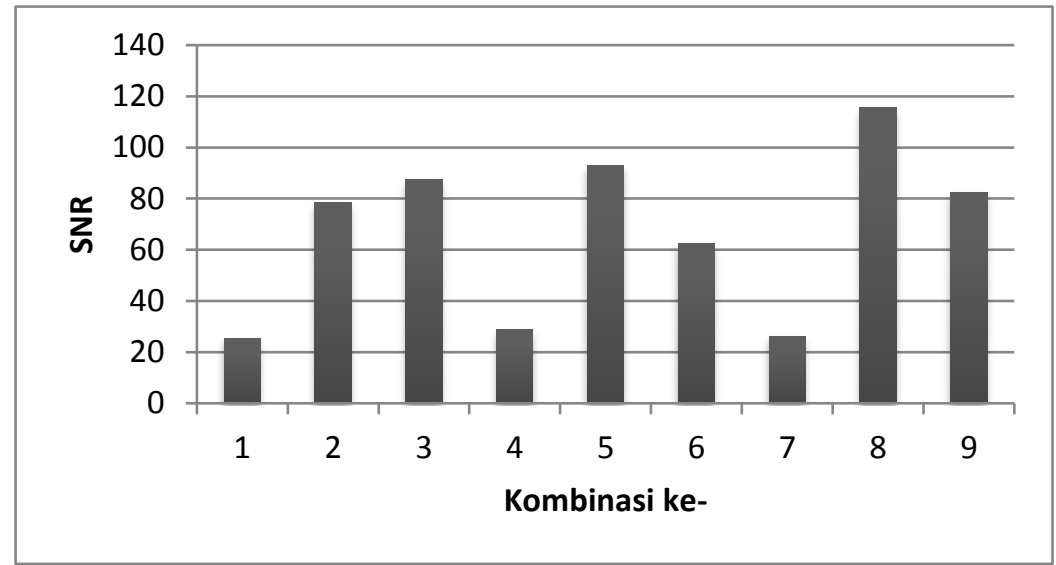

GAMBAR 6. Grafik nilai SNR rata-rata citra normal

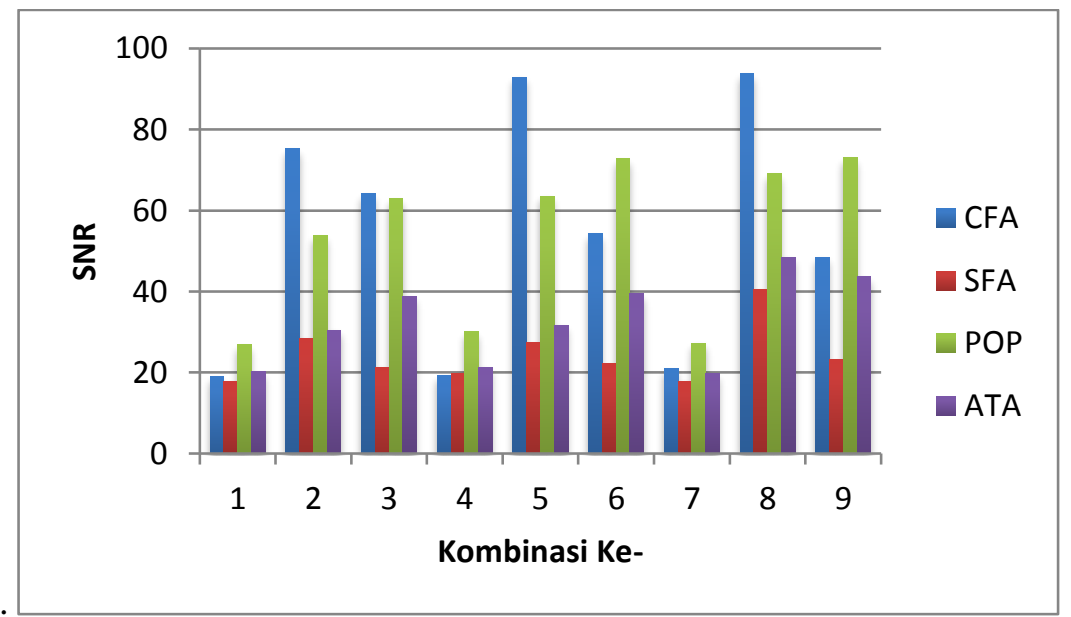

GAMBAR 7. Grafik nilai SNR tiap anatomi citra normal

Berdasarkan nilai SNR pada tabel 3 dan gambar 8 serta 9 citra abnormal tiap kombinasi memiliki keunggulan dalam menghilangkan noise pada citra dengan anatomi tertentu. Namun secara keseluruhan kombinasi 8 menghasilkan SNR rata-rata tertinggi pada citra normal dan abnormal. Kombinasi 8 merupakan gabungan dari filtering gaussian dengan histogram equalization. Filtering gaussian bekerja untuk menghilangkan noise dan menghaluskan citra sehingga dapat mengurangi speckle noise di citra tersebut. Penggunaan kombinasi filtering gaussian dengan histogram equalization menghasilkan anatomi dinding pembuluh darah dengan bagian dalam pembuluh darah menjadi semakin jelas dan meningkatkan nilai SNR yaitu 115,6.

TABEL 3. Nilai SNR citra abnormal

\begin{tabular}{cccccccccc}
\hline \multirow{2}{*}{ Anatomi } & \multicolumn{7}{c}{ Kombinasi } \\
\cline { 2 - 10 } & 1 & 2 & 3 & 4 & 5 & 6 & 7 & 8 & 9 \\
\hline CFA & 29.1 & 93.4 & 124 & 31.8 & 142 & 66.8 & 29.4 & 154 & 110 \\
SFA & 20.7 & 70.4 & 40.2 & 23.1 & 64 & 59 & 19.9 & 63.2 & 79.6 \\
POP & 28.2 & 76.3 & 84.9 & 33.9 & 67.9 & 48.8 & 31.1 & 104 & 51.2 \\
ATA & 23.9 & 74.5 & 101 & 26.7 & 98.6 & 75.6 & 24.4 & 141 & 89.7 \\
\hline Rata-rata & 25.5 & 78.66 & 87.52 & 28.86 & 93.12 & 62.55 & 26.2 & 115.6 & 82.55 \\
\hline
\end{tabular}




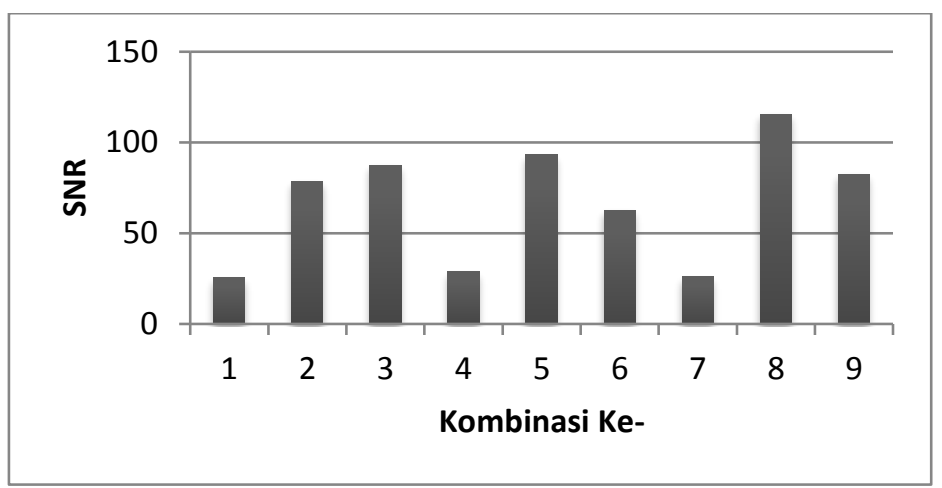

GAMBAR 8. Grafik nilai SNR rata-rata citra abnormal

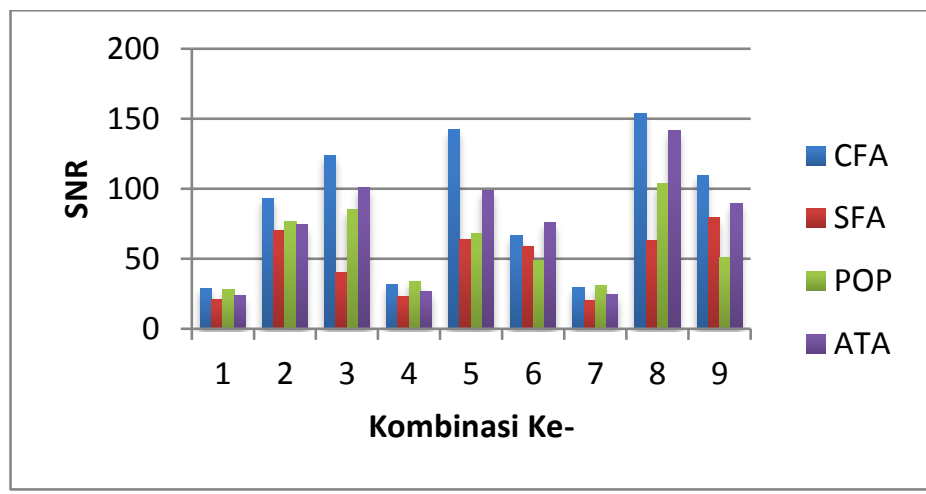

GAMBAR 9. Grafik nilai SNR tiap anatomi citra abnormal

Dengan mengatur intensitas nilai piksel citra sehingga dapat meningkatkan kualitas citra dan menampilkan bentuk visualisasi lebih baik antara objek dan background. Untuk mengamati kerja kombinasi algoritma pengolahan citra dapat dilihat pada gambar 10 . Terlihat bahwa citra asli mengalami perbedaan histogram dengan citra setelah kombinasi. Histogram tersebut menggambarkan bahwa nilai piksel mengalami penyebaran yang tidak merata. Hal itu membuktikan bahwa hasil kombinasi mengalami perubahan histogram merata.

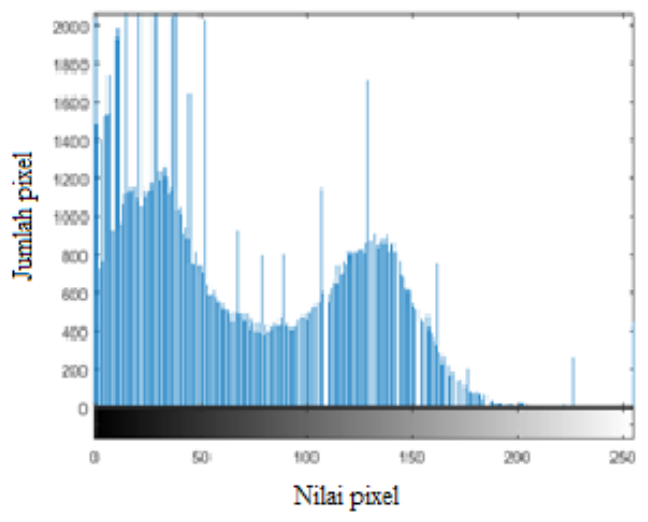

(a)

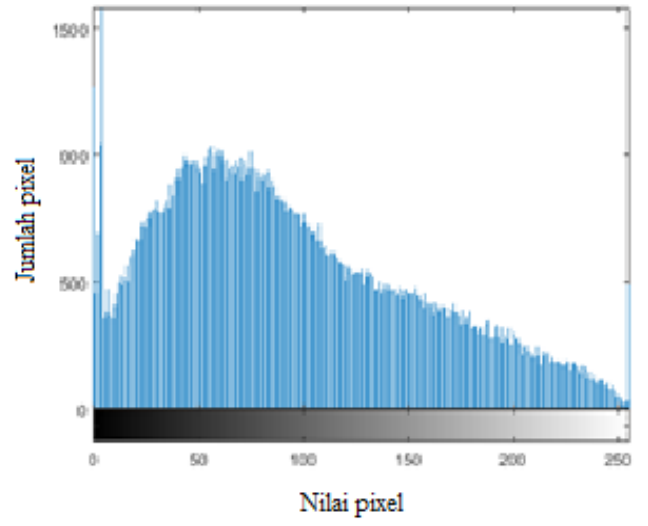

(b)

GAMBAR 10. (a) Histogram Citra (b) Histogram Citra Setelah Kombinasi

\section{Hasil dan Pembahasan Profile Nilai Piksel}

Pengukuran line profie analyze dengan ImageJ dapat dilakukan pada fasilitas menu Analyze lalu pilih tools dan ROI Manager. Lalu membuat garis uji dengan menggunakan straight line tool. Kemudian menggunakan plot profile pada menu analyze tool untuk menghasilkan line profile dan dibuat 5-line dari tiap garis uji. 


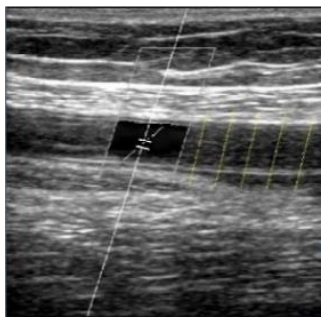

(a)

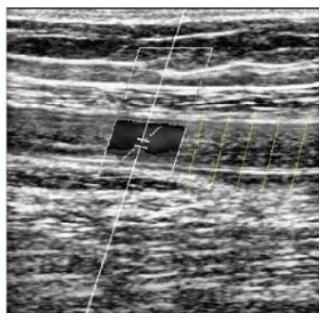

(b)
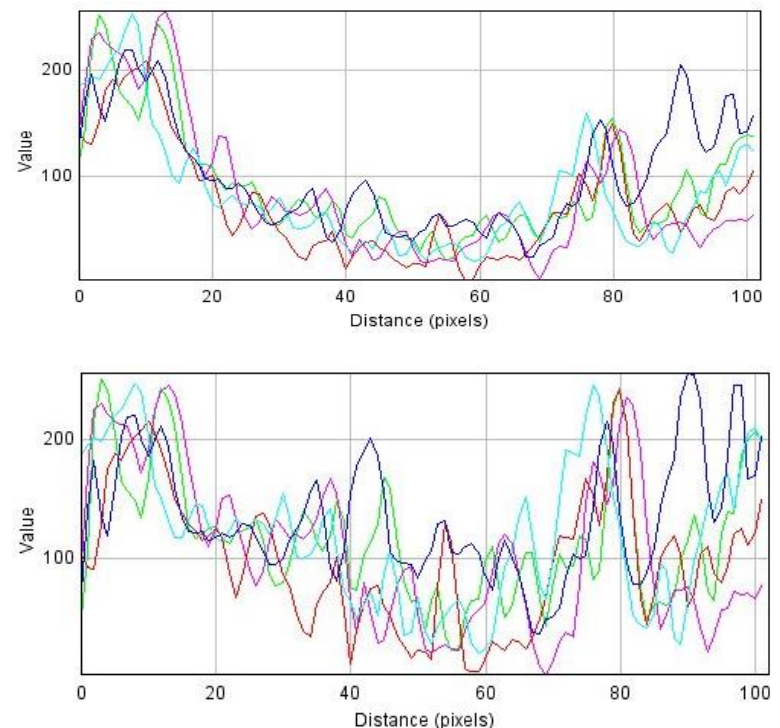

Line 1 Line 2 Line 3 Line 4 Line 5

Line 2 Line 3 Line 4 Line 5

GAMBAR 11. Menunjukan gambar grafik line profile anatomi SFA normal (a) hasil kombinasi filtering gaussian dengan Intensity Adjustment (b) hasil kombinasi filtering median dengan global histogram equalization.

Gambar 11 (a) menghasilkan profile nilai piksel yang terbaik. Karena profile tersebut dapat memperlihatkan perbedaan anatomi dinding pembuluh darah dan aliran darah. Dinding pembuluh darah tersusun atas jaringan lunak yang densitasnya lebih tinggi dari pada darah itu sendiri, maka dalam citra USG dinding pembuluh darah gelap. Dapat terlihat bahwa secara umum bentuk line profile untuk citra normal adalah berbentuk parabola (huruf u). Dimana terdapat lembah dibagian tengah profile. Sedangkan pada gambar 11 (b) menghasilkan profile nilai piksel yang paling buruk dari citra normal SFA. Profile tersebut memperlihatkan perbedaan yang signifikan yaitu memiliki puncak di bagian tengah aliran darah. Puncak tersebut menandakan bahwa dalam citra terdapat nilai piksel tinggi. Nilai piksel yang tinggi akan tampak terang. Maka daerah tersebut yang menunjukan sumbatan pada pembuluh darah.

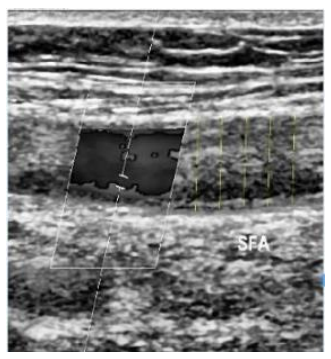

(a)

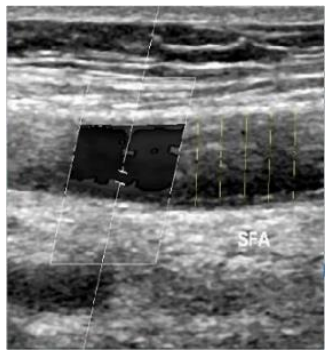

(b)

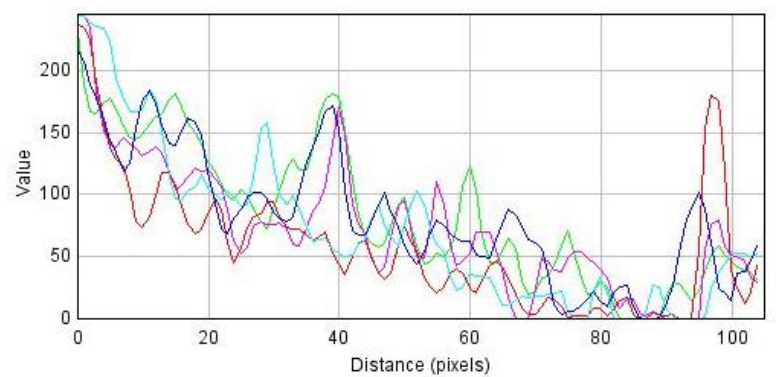

Line 1

Line 2

Line 3

Line 4

Line 5

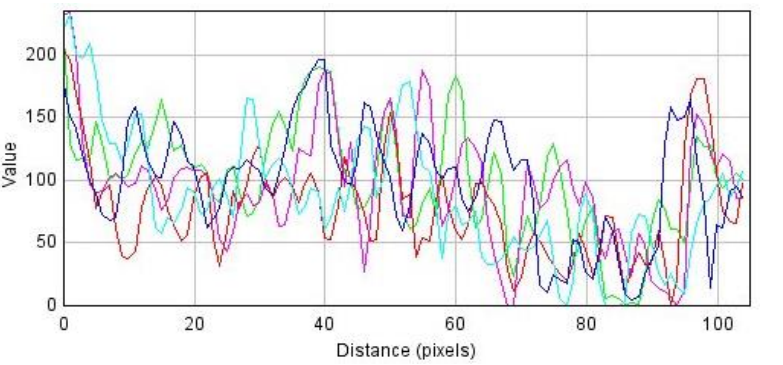

Line 1 -

Line 2

Line 3

Line 4 a

Line 5

GAMBAR 12. Menunjukan gambar grafik line profile anatomi SFA abnormal (a) hasil kombinasi filtering wiener dengan histogram equalization (b) hasil kombinasi filtering gaussian dengan CLAHE. 
Gambar 12 (a) menghasilkan profile nilai piksel yang terbaik dari anatomi SFA abnormal. Karena profile tersebut dapat memperlihatkan perbedaan anatomi dinding pembuluh darah dan aliran darah. Profile citra abnormal tidak berbentuk parabola (huruf u). Terlihat adanya puncak ditengah grafik (aliran darah) yang menandakan nilai piksel tinggi dan mengalami perbedaan densitas. Pada gambar 12 (b) menghasilkan profile nilai piksel yang paling buruk dari citra abnormal SFA. Hasilnya dinding pembuluh darah dan aliran darah hampir sama yaitu memiliki nilai piksel tinggi. Harusnya aliran darah yang normal terlihat gelap. Keberadaan sumbatan yang menyebabkan bagian dalam pembuluh darah tampil dengan warna terang.

\section{KESIMPULAN}

Berdasarkan penjabaran di atas, dapt disimpulkan bahwa citra dengan diagnosis normal menghasilkan profile nilai piksel berbentuk parabola (huruf $\mathrm{U}$ ) dan terdapat lembah dibagian tengah profile. Sementara itu, citra abnormal menghasilkan profile nilai piksel dengan adanya puncak di bagian tengah grafik yang menandakan nilai piksel tinggi (menandakan adanya sumbatan). Secara umum SNR rata-rata tertinggi dihasilkan oleh kombinasi 8 (filtering gaussian dengan global histogram equalization) yang besar SNR yaitu 115.6.

\section{DAFTAR PUSTAKA}

[1] Abdulhannan P, Russell D A dan Homer-Vanniasinkam S. 2012. Peripheral arterial disease: a literature review. British Medical Bulletin; 104:21-39.

[2] Kullo I J dan Rooke T W. 2016. Peripheral artery disease. N ENG J MED; 374:86171.

[3] Rekha Gautam, Ms. Rupali Bharti. 2018. Liver Ultrasound Image Enhancement Using Bilateral Filter. International Journal of Engineering and Technical Research (IJETR) ISSN: 2321-0869 (O) 2454-4698 (P) Volume-8, Issue-4

[4] Shyh-Kuang Ueng, Cho-Li Yen, and Guan-Zhi Chen. 2014. Ultrasound Image Enhancement Using Structure-Based Filtering. Computational and Mathematical Methods in Medicine. Page: 758439

[5] Abdulhannan P, Russell D A dan Homer-Vanniasinkam S. 2012. Peripheral arterial disease: a literature review. British Medical Bulletin. 104:21-39.

[6] Kullo I J dan Rooke T W. 2016. Peripheral artery disease. N ENG J MED. 374:861 71.

[7] Wan Nur Hafsha Wan Kairuddin and Wan Mahani Hafizah Wan Mahmud. 2017. Texture Feature Analysis for Different Resolution Level of Kidney Ultrasound Images. IOP Conf. Ser.: Mater. Sci. Eng. 226012136

[8] Wan, M. H. 2011. Optimization of Pancreas Measurement Techniques Based on Ultrosound Images. Johor Bahru

[9] Wan, M. H. 2011. Comparative Evaluation of Ultrasound Kidney Image Enhancement Techniques. Johor Bahru.

[10] Ognjen Magud, Eva Tuba And Nebojsa Bacanin. 2016. An Algorithm for Medical Ultrasound Image Enhancement by Speckle Noise Reduction. International Journal of Signal Processing, Volume 1, ISSN: 2367-8984 